Note

\title{
PHYSICAL AND CHEMICAL CHANGES DURING RIPENING OF BLACKBERRY FRUITS
}

\author{
Ilkay Tosun $^{1}$; N. Sule Ustun ${ }^{1 *}$; Belkis Tekguler ${ }^{1}$ \\ I'Ondokuz Mayis University/Faculty of Engineering - Dept. of Food Engineering - 55139 - Kurupelit, Samsun - \\ Turkey. \\ *Corresponding author<sustun@omu.edu.tr>
}

\begin{abstract}
Blackberry (Rubus L.) is a naturally growing fruit in Anatolia. Consumption of fresh and frozen blackberries has increased in the past few years in Turkey. The aim of this study is to analyze blackberry at three levels of ripeness taking into account some physical and chemical properties (color, dry matter, soluble solids, total sugar, titratable acidity, $\mathrm{pH}$, total phenolics, total anthocyanin, and minerals) in order to understand this behavior during the ripening process. Blackberry fruits were harvested at green, red and ripe (mature) stages. The determination of fruit maturity was based on fruit surface color. The dry matter, total phenolics and Hunter L, b values decreased but soluble solids, total sugar and total anthocyanins increased with maturity. In the early fruit ripening stages, $\mathrm{pH}$ decreased, titratable acidity and Hunter a value increased while in the later stages, $\mathrm{pH}$ increased, titratable acidity and Hunter a value decreased considerably. Analysis of variance revealed $(P<0.01)$ differences in these parameters based on ripeness stages. No remarkable changes in potassium, calcium, zinc and manganese concentrations occured during the development of fruits. Differences were observed for magnesium $(P<0.01)$, iron $(P<0.01)$ and copper $(P<0.05)$ during ripening of blackberry.
\end{abstract}

Key words: Rubus L., color, anthocyanin, mineral matter

\section{MUDANÇAS FÍSICAS E QUÍMICAS DURANTE A MATURAÇÃO DE FRUTOS DE AMORA PRETA}

\begin{abstract}
RESUMO: Amora preta (blackberry, Rubus L.) é uma fruta que cresce naturalmente na península de Anatolia. O consumo de suas frutas frescas ou congeladas aumentou nos últimos anos na Turquia. Este estudo teve por objetivo analisar amoras pretas colhidas em três níveis de maturação, levando em conta propriedades físicas e químicas das frutas (cor, matéria seca, sólidos solúveis, açúcar total, acidez titulável, $\mathrm{pH}$, fenóis totais, antocianina total e sais minerais) para melhor compreender o processo de maturação. As frutas foram colhidas nos estágios verde, vermelho e maduro. A determinação do estágio maduro foi baseada na cor da superfície das frutas. A materia seca, os fenóis totais e os valores de Hunter L, b diminuiram mas os sólidos solúveis, açúcares totais e total de antocianina decresceram em função do nível de maturação. Nos estágios iniciais de maturação, o pH decresceu, a acidez titulável e o valor a de Hunter aumentaram enquanto nos estágios posteriores o pH aumentou, a acidez titulável e o valor a de Hunter decresceram consideravelmente. A análise de variância revelou diferenças nestes parâmetros $(P<0,01)$, baseada nos estágios de maturação. Não houve mudanças marcantes nos conteúdos de potássio, calico e magnésio durante o desenvolvimento dos frutos. Diferenças foram obsevadas para magnésio $(P<0,01)$, ferro $(P<0,01)$ e cobre $(P<0,05)$ durante a maturação das amoras pretas.

Palavras-chave: Rubus L., cor, antocianina, conteúdo mineral
\end{abstract}

\section{INTRODUCTION}

For most fruit ripening processes corresponds a number of coordinated biochemical and physiological processes. The evolution of some components during the development of fruits have been studied previously (Woodward, 1972; Naumann \& Wittenburg, 1980; Al-Kaisy et al., 1981; Chapman \& Horvat, 1990;
Ackermann et al., 1992; Perkins-Veazie et al., 1996; Hernández et al., 1999; Wang \& Lin, 2000; AlarcãoE-Silva et al., 2001; Aydın \& Kadioğlu, 2001; Moing et al., 2001; Raffo et al., 2004; Siriwoharn et al., 2004). Perkins-Veazie et al. (1996) evaluated changes in titratable acidity and soluble solids of blackberry cultivars at three maturity stages. Wang \& Lin (2000) evaluated the antioxidant capacity, total phenolic and total 
anthocyanin contents in green, pink and ripe developmental stages of blackberry fruits.

Numerous physical, chemical and biochemical changes occur during the ripening of blackberry (Rubus L.) wildly grown in Turkey. The aim of this work was to evaluate and quantify some physical and chemical changes during the maturation of blackberry fruits.

\section{MATERIAL AND METHODS}

Nine genotypes of wild mountainous blackberry fruits were harvested during August-September 2005 from Kavak $\left(41^{\circ} 31^{\prime}\right.$ N, 35 35' E, 600 m) in Samsun, Turkey. Fruits were tetraploid upright types showing a gradual ripening change from solid green to reddish green to red hard stage to red fleshly stage and then to black. Multiple harvests of fruit at green, red and ripe (black) maturity stages were made over a six-week period. The determination of fruit maturity was based on fruit surface color. Fruits were transported on ice from the bushes to the laboratory and packed in evacuated plastic bags and stored at a temperature of $-20^{\circ} \mathrm{C}$ (for two months) until analysis. After thawing at $4^{\circ} \mathrm{C}$, the samples were chopped and homogenized in a Waring blender and subjected to the following analysis.

Fruit color was evaluated by measuring Hunter L (brightness, $100=$ white, $0=$ black), a (+, red; -, green) and b (+, yellow; -, blue) parameters by means of a reflectance colorimeter (CR 300, Chromometer, Minolta, Japan). A white tile (No: 21733001) was used to standardize the instrument. Dry matter was determined by drying fruits at $70^{\circ} \mathrm{C}$ under vacuum (AOAC, 1984). The total soluble solids contents of samples were measured at $20^{\circ} \mathrm{C}$ on an Abbe refractometer (Japan). Total sugar was estimated by the Luff-Schrool volumetric method (Lees, 1975), $\mathrm{pH}$ was determined at $20^{\circ} \mathrm{C}$. Titratable acidity was determined by titration to $\mathrm{pH} 8.1$ with $0.1 \mathrm{M} \mathrm{NaOH}$ solution and calculated as grams of citric acid per $100 \mathrm{~g}$ of sample (AOAC, 1984). The amount of total phenolics was measured at $720 \mathrm{~nm}$ by the Folin-Ciocalteu reagent (AOAC, 1965) and expressed as catechin equivalents. Total anthocyanin content was determined by the $\mathrm{pH}$ differential method as described by Wrolstad (1976). Absorbance at $515 \mathrm{~nm}$ was used to calculate Cyanidine-3-glucoside equivalents $(\mathrm{MW}=445.2, \mathrm{e}=29,600)$. Mineral contents were analyzed by means of atomic absorption spectroscopy (Perkin Elmer, Model 3100) having previously mineralized the samples (Kacar, 1972).

\section{Statistical analysis}

The experimental design was randomized with three treatments and nine replications. Data were submitted to variance analysis (ANOVA) and the averages compared by the Duncan's multiple range test at $P<0.05$ and $P<0.01$ using the MSTAT program.

\section{RESULTS AND DISCUSSION}

The Hunter L value decreased with fruit ripening as color became deep/dark (Table 1). Being an index of redness and greenness, the Hunter a value increased in the early fruit ripening stages, while in the ripe mature stage, because of the violet color development, the Hunter a value decreased. The Hunter $\mathrm{b}$ value, expressing yellowness and blueness decreased $(P<0.01)$ with maturity. Dry matter changes in the blackberry samples decreased $(P<0.01)$ as the fruit ripened. During ripening, a slight and insignificant increase in the soluble solids content occurred at the green and red ripening stages, but at the ripe stage, the change in soluble solids was

Table 1 - Some physical and chemical properties of the blackberry in different maturation stages (means \pm standard deviation).

\begin{tabular}{lrrr}
\hline Properties & green & red & ripe \\
\hline L & $40.76 \pm 2.81 \mathrm{a}$ & $34.23 \pm 2.57 \mathrm{~b}$ & $17.35 \pm 1.45 \mathrm{c}$ \\
$\mathrm{A}$ & $-1.68 \pm 0.85 \mathrm{c}$ & $30.89 \pm 1.51 \mathrm{a}$ & $10.41 \pm 3.26 \mathrm{~b}$ \\
$\mathrm{~B}$ & $24.06 \pm 0.95 \mathrm{a}$ & $13.07 \pm 0.92 \mathrm{~b}$ & $3.62 \pm 1.24 \mathrm{c}$ \\
\hline Dry matter, \% & $21.30 \pm 0.93 \mathrm{a}$ & $17.31 \pm 1.08 \mathrm{~b}$ & $15.43 \pm 6.20 \mathrm{c}$ \\
Soluble solids, \% & $7.00 \pm 0.35 \mathrm{~b}$ & $7.39 \pm 0.70 \mathrm{~b}$ & $11.11 \pm 0.74 \mathrm{a}$ \\
\hline Total sugar, g kg-1* & $45.81 \pm 9.50 \mathrm{c}$ & $96.90 \pm 17.14 \mathrm{~b}$ & $485.48 \pm 37.68 \mathrm{a}$ \\
pH & $3.20 \pm 0.13 \mathrm{a}$ & $2.64 \pm 0.04 \mathrm{~b}$ & $3.14 \pm 0.14 \mathrm{a}$ \\
Titratable acidity, \%* & $6.98 \pm 1.14 \mathrm{~b}$ & $14.80 \pm 1.15 \mathrm{a}$ & $5.78 \pm 1.40 \mathrm{~b}$ \\
Protein, \%* & $67.96 \pm 8.21$ & $53.85 \pm 6.28$ & $40.59 \pm 6.49$ \\
Total phenolics, mg kg & 14 & $9,949.59 \pm 2,076.10$ & $9,368.25 \pm 1,259.43$ \\
Total anthocyanin, $\mathrm{mg} \mathrm{kg}^{-1 *}$ & $-572.44 \pm 3,917.32$ & $1,009.02 \pm 240.53 \mathrm{~b}$ & $7,926.71 \pm 1,607.09 \mathrm{a}$ \\
\hline
\end{tabular}

* Dry weight basis. Line values with the same letter are not different $(P<0.01)$. 
Table 2 - Changes in mineral contents during blackberry maturation (means \pm standard deviation).

\begin{tabular}{lccc}
\hline Properties & green & red & ripe \\
\hline & & & \\
Potassium & $14,586.27 \pm 2,957.96$ & $15,398.95 \pm 8,847.82$ & $13,755.02 \pm 3,300.52$ \\
Calcium & $961.27 \pm 353.27$ & $670.70 \pm 107.38$ & $817.51 \pm 387.46$ \\
Zinc & $29.02 \pm 6.85$ & $25.68 \pm 5.41$ & $28.34 \pm 10.89$ \\
Manganese & $42.05 \pm 8.85$ & $50.78 \pm 20.75$ & $52.68 \pm 9.01$ \\
Magnessium** & $4,513.65 \pm 1,298.85 \mathrm{a}$ & $2,493.76 \pm 718.37 \mathrm{~b}$ & $2,903.36 \pm 1,508.13 \mathrm{~b}$ \\
Copper* & $11.3 \pm 4.48 \mathrm{~b}$ & $15.41 \pm 5.59 \mathrm{a}$ & $10.66 \pm 3.21 \mathrm{~b}$ \\
Iron** & $50.39 \pm 10.90 \mathrm{~b}$ & $77.67 \pm 16.41 \mathrm{a}$ & $70.12 \pm 12.26 \mathrm{a}$ \\
\hline
\end{tabular}

*Line values with the same letter are not different $(P<0.05)$. ** Line values with the same letter are not different $(P<0.01)$.

significant $(P<0.01)$. Perkins-Veazie et al. (1996), Perkins-Veazie et al. (2000) and Naumann \& Wittenburg (1980) found similar results for blackberries. The total sugar content also increased $(P<0.01)$ with ripening. Similar results were reported by Woodward (1972), Chapman \& Horvat (1990), Ackermann et al. (1992), Aydın \& Kadiǒ̆lu (2001) and Moing et al. (2001) for apples, peaches, strawberries and medlar fruits, respectively. Water, soluble solids and sugar concentrations increased continuously during fruit development.

Titratable acidity increased during development, but was less in ripe fruits. Acidity was inversely correlated to $\mathrm{pH}$. The ripe sample which had a low acid content had a correspondingly high $\mathrm{pH}$. Evolution of titratable acids and the $\mathrm{pH}$ of blackberry recorded above agree with published data on strawberries (Woodward, 1972; Moing et al., 2001). Organic acids usually decline during ripening as they are respired or converted to sugars.

Having health beneficial properties, phenolic matters decreased with ripening, whereas no significant differences were found between the green and red maturity stages. Anthocyanins is a member of the group of phenolics that contributes to the red, blue, or purple colours of fruits. Being responsible from the color of blackberries, anthocyanins presented an increase $(P<0.01)$ as the ripening proceeded. The changes in total anthocyanin concentrations agree with Hernández et al. (1999) for pomegranate, while the changes in total phenolics and anthocyanin concentrations agree with Perkins-Veazie et al. (2000) and Wang \& Lin (2000) for blackberry and Alarcão-E-Silva et al. (2001) for Arbutus berry.

In this study, while potassium, calcium, zinc and manganese contents exhibited moderate changes, magnesium, copper and iron presented changes throughout the ripening period (Table 2). Insertion of magnesium into the porphyrin structure is the first step of chlorophyll biosynthesis (Marschner, 1995). The most significant changes in ripening were observed for magnesium, which is the central atom of the chlorophyll molecule, and iron and copper, functioning in chlorophyll synthesis. Potassium, copper, iron and manganese concentrations increased during the reddening period and decreased in the ripe mature stage. During fruit development, the calcium content of the cell walls increased to the fully grown immature stage, but this was followed by a drop in the content and change in the binding form of calcium in the tissue just before ripening (softening of the tissue) (Marschner, 1995) Magnesium also evolves similarly. However, after ripening the calcium and magnesium again accumulate in the cell wall and their concentrations increase during the fully mature stage.

Hunter L, b, dry matter and total phenolics decreased, soluble solids, total sugar, total anthocyanins increased with ripening; $\mathrm{pH}$ decreased between green and red stages and increased between red and ripe stages; titratable acidity and Hunter a value increased between green and red stages of ripening and decreased between red and ripe stages. All of these changes were significant $(P<0.01)$. Ripening had no effect on potassium, calcium, zinc and manganese, however the changes in copper concentration $(P<0.05)$ and magnesium and iron concentrations $(P<0.01)$ were significant.

\section{REFERENCES}

ACKERMANN, J.; FISCHER, M.; AMADO, R. Changes in sugars, acids, and amino acids during ripening and storage of apples (Cv.Glockenapfel). Journal of Agricultural and Food Chemistry, v.40, p.1131-1134, 1992.

ALARCÃO-E-SILVA, M.L.C.M.M.; LEITÃO, A.E.B.; AZENHEIRA, H.G.; LEITÃO, M.C.A. The arbutus berry: studies on its color and chemical characteristics at two mature stages. Journal of Food Composition and Analysis, v.14, p.27$35,2001$.

AL-KAISY, A.M.; SACHDE, A.G.; GHALIB, H.A.; HAMEL, S.M. Physical and chemical changes during ripening of some grape varieties grown in Basrah. American Journal of Enology and Viticulture, v.32, p.268-271, 1981. 
ASSOCIATION OF OFFICIAL ANALYTICAL CHEMISTS AOAC. Official methods of analysis of the Association of Official Analytical Chemists. 10 ed. Washington, DC: AOAC, 1965. 9.060.

ASSOCIATION OF OFFICIAL ANALYTICAL CHEMISTS AOAC. Official methods of analysis of the Association of Official Analytical Chemists. 14 ed. Washington, DC: AOAC, 1984. 22.013, 22.059.

AYDIN, N.; KADIOGLU, A. Changes in the chemical composition, polyphenol oxidase and peroxidase activities during development and ripening of medlar fruits (Mespilus germanica L.). Bulgarian Journal of Plant Physiology, v.27, p.85-92, 2001.

CHAPMAN, G.W.J.; HORVAT, R.J. Changes in nonvolatile acids, sugars, pectin, and sugar composition of pectin during peach (Cv. Monroe) maturation. Journal of Agricultural and Food Chemistry, v.38, p.383-387, 1990.

HERNÁNDEZ, F.; MELGAREJO, P.; TOMÁS-BARBERÁN, F.A.; ARTÉS, F. Evolution of juice anthocyanins during ripening of new selected pomegranate (Punica granatum) colones. European Food Research and Technology, v.210, p.39-42, 1999.

KACAR, B. Bitki ve topra 1n kimyasal analizleri. II. Bitki analizleri. Ankara Universitesi Ziraat Fakültesi Yay1nlar1 ${ }^{\circ}$ 453, 1972. p.47-49.

LEES, R. Food analysis: analytical and quality control methods for the manufacturer and buyer. 3.ed. London: Leonard Hill, 1975. p. 145-146.

MARSCHNER, H. Mineral nutrition of higher plants. 2. ed. New York: Academic Pres, 1995. p.278-290.

MOING, A.; RENAUD, C.; GAUDILLERE, M.; RAYMOND, P.; ROUDEILLAC, P.; DENOYES-ROTHAN, B. Biochemical changes during fruit development of four strawberry cultivars. Journal of the American Society for Horticultural Science, v.126, p.394-403, 2001.
NAUMANN, W.D.; WITTENBURG, U. Anthocyanins, soluble solids, and titratable acidity in blackberries as influenced by preharvest temperatures. Acta Horticulturae, v.112, p.183190, 1980.

PERKINS-VEAZIE, P.; COLLINS, J.K.; CLARK, J.R. Cultivar and maturity affect postharvest quality of fruit from erect blackberries. HortScience, v.31, p.258-261, 1996.

PERKINS-VEAZIE, P.; CLARK, J.R.; HUBER, D.J.; BALDWIN, E.A. Ripening physiology in "Navaho" thornless blackberries: color, respiration, ethylene production, softening and compositional changes. Journal of the American Society for Horticultural Science, v.125, p.357-363, 2000.

RAFFO, A.; PAOLETTI, F.; ANTONELLI, M. Changes in sugar, organic acid, flavonol during ripening of berries of three seabuckthorn (Hippophae rhamnoides L.) cultivars. European Food Research and Technology, v.219, p.360-368, 2004.

SIRIWOHARN, T.; WROLSTAD, R.E.; FINN, C.E.; PEREIRA, C.B. Influence of cultivar, maturity, and sampling on blackberry (Rubus L. Hybrids) anthocyanins, polyphenolics, and antioxidant properties. Journal of Agricultural and Food Chemistry, v.52, p.8021-8030, 2004.

WANG, S.Y.; LIN, H-S. Antioxidant activity in fruits and leaves of blackberry, raspberry, and strawberry varies with cultivar and developmental stage. Journal of Agricultural and Food Chemistry, v.48, p.140-146, 2000

WOODWARD, J.R. Physical and chemical changes in developing strawberry fruits. Journal of Science of Food and Agriculture, v.23, p.465-473, 1972.

WROLSTAD, R.E. Color and pigment analyses in fruit products. Corvallis: Oregon State University, 1976. p.1-17. (Agricultural Experiment Station Bulletin, 624).

Received February 17, 2006

Accepted September 26, 2007 